\title{
Utilization of Vinasse and Feldspar as Alternative Sources of Potassium Fertilizers and Their Effect on Some Soil Properties and Crop Yield in Sandy Soils \\ Wafaa M.A. Seddik ; Mona A. Osman and Mona H.M. Kenawy \\ Soil, Water and Environ. Res. Inst., Agric. Res. Center, Giza, Egypt
}

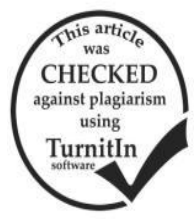

\section{ABSTRACT}

A field experiment was carried out for two successive seasons (winter season 2013/2014 and summer season 2014 ) on sandy soil at Ismailia Agric. Res. Station , Ismailia Governorate, Egypt (Latitude, 30 35' 41.901" N and longitude, 32 ${ }^{\circ} 16^{\prime}$ $45.834 \mathrm{"E}$ ) to investigate the utilization of vinasse and feldspar as alternative sources of potassium fertilizers on crop yield (pea and peanut), nutritional status and some soil properties. Two rates of vinasse V1 (75\%) and V2 (100\%) and two rates of feldspar mineral F1 (75\%) and F2 (100\%) from the recommended dose of potassium were used to complete the recommended dose of $\mathrm{K}$ fertilizers for pea and peanut crops, combination application of vinasse and feldspare were added as follow; $(25 \% \mathrm{~V}+75 \% \mathrm{~F})$, $(50 \% \mathrm{~V}+50 \% \mathrm{~F})$ and $(75 \% \mathrm{~V}+25 \% \mathrm{~F})$. Results show that available $\mathrm{N}, \mathrm{P}$ and $\mathrm{K}$ in soil increased significantly by increasing the rate of applied vinasse and feldspar mineral. The superior treatment was $(75 \% \mathrm{~V}+25 \% \mathrm{~F})$, while, the $\mathrm{pH}$ values of soil and those of EC and OM \% increased. The highest values of EC and OM \% being recorded with vinasse (V2) and vinasse combined with feldspar $(75 \% \mathrm{~V}+25 \% \mathrm{~F})$. Total phenols values increased gradually by increasing the rate of vinasse, as compared to control treatment and decreased gradually with depth, the highest values of total phenols were recorded for the soil surface layer in presence of $100 \%$ vinasse alone followed by vinasse combined with feldspar. At the same time, the partially use of vinasse as a K fertilization in sandy soils is not causing any bioaccumulation of phenol compounds in sub soil layers. Results indicated that value of field capacity (FC), wilting point (WP) and available water (AW) increased by application of vinasse and feldspar mineral compared to control treatment at both studied seasons. Also data demonstrated that increasing rates of vinasse and feldspar mineral significantly increased (FC), (WP) and (AW) values. The high rate of vinasse (V2) and feldspar mineral (F2) being superior. Moreover, application of vinasse at rate $75 \%$ combined with feldspar at rate $25 \%$ had recorded the highest values of soil moisture characteristics (FC, WP and AW). Moreover, application of vinasse at a rate of $75 \%$ combined with feldspar at a rate of $25 \%$ had recorded the highest values of yield components as well as (N, P and $\mathrm{K}$ ) total contents of grains and straw for both pea and peanut crops as compared to either control or other treatments. The application of vinasse combined with feldspar mineral $(75 \% \mathrm{~V}+25 \% \mathrm{~F})$ could be considered as a replacement for $\mathrm{K}$ - mineral fertilizers in sandy soils.

Keywords: Vinasse, Feldspar, Soil Properties, Phenols, Pea, Peanut

\section{INTRODUCTION}

Potassium fertilizers play an important role in agriculture. The crop production in Egypt relies greatly on imports to meet its requirement of potassium fertilizers. In order to reduce the dependence on imported potassium fertilizers. Alternative potassium sources such as feldspar and or organic byproduct such as vinasse must be considered. The main source of $\mathrm{K}$ for plants growing under natural conditions comes from the weathering of $\mathrm{K}$ minerals and organic $\mathrm{K}$ - sources such as compost and plant residues. The most important $\mathrm{K}$ minerals are K-feldspar, leucite, K-mica such as biotite, phlogopite and glauconite and clays such as illite (Badr, 2006).Potassium from feldspar mineral may be solubilized and transformed into available form when incorporated with organic materials such as (compost or vinasse). Seddik, ( 2006) indicated that applying feldspar combined with rice straw compost or chicken manure and inoculation with Bacillus pasteurii led to decrease soil bulk density and increase total porosity as well as improve the nutritional status and increase yield of peanut. Abd El-Motty et al. (2009) showed that application of feldspar in combination with compost to olive rose up the macro and micro nutrients percentage in leaves of olive than the control treatment.

Vinasse is a by-product from ethanol production. Vinasse contains a lot of organic matter, potassium, nitrogen and other plant nutrients that is regularly used as soil fertilizer (Silva et al., 2015). Furthermore, vinasse improves factors involved in soil fertility, provides favoring conditions for nitrogen assimilation into the soil, protects nutrients against washing out and maintains them as reserve nutrients, leading to increase yield and quality of crop (Rodriguez, 2000).

Also, vinasse application to sandy soils increased the productivity of wheat yield and uptake of nitrogen, phosphorus and potassium. The residual available N, P, $\mathrm{K}$ and organic matter in the soil after harvesting generally increased with increasing the rate of applied vinasse (Arafat and Abd-Elazim 2002). Moreover, Vadivel et al.,(2014) found that appropriate time and rate of vinasse application in agriculture has added significant amounts of nutrients, improved the soil quality of degraded land and increase crop yields.

Luz (2005) and Osman (2010) mentioned that vinasse can partially replace the fertilizers that uses potassium and sulfur and partially replace fertilization with nitrogen. Furthermore, Parnaudeau et al. (2007) mentioned that, vinasse used as an organic fertilizer. Vinasse led to a slight increase in the abundance of phenolic compounds, acids, insoluble fractions. Armengol et al. ( 2003) reported that vinasse application in agriculture have been reported positive feedback to some properties i.e. bulk density, porosity, water retention, stable aggregates and structure formation, infiltration, hydraulic conductivity, soil reaction, nutrient availability, improved nutrient use efficiency and soil biochemical properties and eventually the crop growth and development .

Recently, Jiang et al. (2012) found that application of vinasse at the rate of $75 \mathrm{t} / \mathrm{ha}$ increased the macro aggregates over farmer practices and had more of larger size $(>1 \mathrm{~mm})$ aggregates with high amount of biodegradable carbon and nitrogen that has more significance to soil fertility. 
Seddik (2011) showed that application of feldspar in combination with vinasse improved soil physical properties and increased availability of macronutrients in soil, wheat yield components as well as $\mathrm{N}, \mathrm{P}$ and $\mathrm{K}$ contents of grains and straw of wheat.

Vinasse contains a kind of pollutants such as phenolic compounds and pigments like melanoidins, which may inhibit the activity of microorganisms (Figaro et al., 2006). On the other hand, BioBizz Worldwide (2011) reported that there is no bioaccumulation of vinasse or its components as it has a high decomposition rate by micro-organisms in either soil or water and do not accumulate. Moreover, safety information including Material Safety Data Sheet (MSDS) report from National Institute of Environmental Health Studies (Tate and Lyle, 2005) showed no hazard substance from beet or sugar cane vinasse, or any industrial waste from the sugar industry.

Filho et al. (1996) and Osman et al. (2016) found that continuous application of vinasse in sandy soils of peanut and carrot do not cause accumulation of phenolic compounds.

The objectives of this study are to investigate the utilization of vinasse and feldspar as alternative sources of potassium fertilizers and its effects on some soil properties and nutritional status of pea and peanut in sandy soils.

\section{MATERIALS AND METHODS}

A field experiment was carried out for two successive seasons. Pea (PisumSativum L.) was planted during winter season (2013/2014) and peanut ( Arachishypogaea)was planted during summer season (2014) on a sandy soil under drip irrigation system at Ismailia Agric. Res. Station, A.R.C (Latitude, 30o 35' 41.901" N and longitude, 32o 16' 45.834" E). The experiment was designed in a complete randomized block design with three replications. Control treatment received the recommended mineral fertilizers, $200 \mathrm{Kg}$ $\mathrm{fed}^{-1}$ as ammonium sulphate $(20.5 \% \mathrm{~N}), 100 \mathrm{Kg} \mathrm{fed}^{-1}$ superphosphate $\left(15.5 \% \mathrm{P}_{2} \mathrm{O}_{5}\right)$ and $50 \mathrm{Kg} \mathrm{fed}^{-1}$ potassium sulphate $\left(48 \% \mathrm{~K}_{2} \mathrm{O}\right)$ for pea crop and $150 \mathrm{Kg} \mathrm{fed}^{-1}$ as ammonium sulphate $(20.5 \% \mathrm{~N}), 200 \mathrm{Kg} \mathrm{fed}^{-1}$ superphosphate $\left(15.5 \% \mathrm{P}_{2} \mathrm{O}_{5}\right)$ and $50 \mathrm{Kg} \mathrm{fed}^{-1}$ potassium sulphate $\left(48 \% \mathrm{~K}_{2} \mathrm{O}\right)$ for peanut crop.

Some physical and chemical properties of the studied soil before cultivation are shown in Table (1).

All treatments received a recommended dose from ammonium sulphate $(20.5 \% \mathrm{~N})$ and super phosphate $\left(15 \% \mathrm{P}_{2} \mathrm{O}_{5}\right)$ along with rice straw compost 5 $\mathrm{m}^{3} \mathrm{fed}^{-1}$. While potassium fertilizer was added from two alternative sources (vinasse $\{\mathrm{V}\}$ and feldspar $\{\mathrm{F}\}$ ).

Feldspar and vinasse were added at $75 \%$ and 100 $\%$ of the potassium recommended dose for pea and peanut crops. Potassium fertilizer sources were applied alone or in combination $(25 \% \mathrm{~V}+75 \% \mathrm{~F}),(50 \% \mathrm{~V}+$ $50 \% \mathrm{~F})$ and $(75 \% \mathrm{~V}+25 \% \mathrm{~F})$ for both pea and peanut crops. Feldspar was added by thoroughly mixing with the surface soil layer $(0-15 \mathrm{~cm})$ two weeks before pea and peanut cultivation as $360 \mathrm{~kg} \mathrm{fed}^{-1}(75 \%)$ and $480 \mathrm{~kg}$ $\mathrm{fed}^{-1}(100 \%)$ from the recommended dose , respectively, while vinasse treatments were sprayed two weeks after planting on soil surface three times along the period of plant growth after (2,4 and 6 weeks) from planting as $565.5 \mathrm{~L} \mathrm{fed}^{-1}(75 \%)$ and $750 \mathrm{~L} \mathrm{fed}^{-1}(100 \%)$ from the recommended dose, respectively.

Vinasse was provided by the integrated industries and sugar Company, EL-Hawamdia, Egypt. Some chemical characteristics of vinasse and feldspar used in this study(Cottenie et al.,1982) are presented in Table (2).

Table 1. Some physical and chemical properties of the experimental soil

\begin{tabular}{|c|c|c|c|}
\hline Soil characteristics & Values & $\begin{array}{c}\text { Soil } \\
\text { characteristics }\end{array}$ & Values \\
\hline Particle size & \multirow{9}{*}{$\begin{array}{c}50.4 \\
40.4 \\
3.20 \\
6.0 \\
\text { Sandy }\end{array}$} & $\begin{array}{l}\text { Soluble cations and } \\
\text { anions }\left(\mathrm{meq} \mathrm{L}^{-1}\right)\end{array}$ & \\
\hline \multirow[t]{2}{*}{ distribution $\%$} & & $\mathrm{Ca}^{++}$ & 0.95 \\
\hline & & $\mathrm{Mg}^{++}$ & 0.89 \\
\hline Coarse sand & & $\mathrm{Na}^{+}$ & 1.50 \\
\hline Fine sand & & $\mathrm{K}^{+}$ & 0.45 \\
\hline Silt & & $\mathrm{CO}_{3}^{--}$ & - \\
\hline Clay & & $\mathrm{HCO}_{3}^{-}$ & 1.42 \\
\hline \multirow[t]{2}{*}{ Texture class } & & $\mathrm{Cl}^{-}$ & 1.02 \\
\hline & & $\mathrm{SO}_{4}^{--}$ & 1.35 \\
\hline Chemical properties & & Available nutrients (mg & \\
\hline $\mathrm{pH}$ (suspension $1: 2.5$ ) & & $\left.\mathrm{Kg}^{-1}\right)$ & \\
\hline $\mathrm{EC} \mathrm{dSm}^{-1}$ (saturated & 1.10 & $\mathrm{~N}$ & 45 \\
\hline soil paste extract) & $\begin{array}{ll}0.37 \\
0.38\end{array}$ & $\mathrm{P}$ & 11 \\
\hline Organic matter \% & 0.38 & $\mathrm{~K}$ & 83 \\
\hline
\end{tabular}

Table 2. Some chemical characteristics of vinasse and feldspar

\begin{tabular}{|c|c|c|}
\hline Characteristics & Vinasse & Feldspar \\
\hline$\overline{\mathrm{pH}}$ & 4.20 & 8.56 \\
\hline $\mathrm{EC} \mathrm{dSm}^{-1}$ & 20.0 & 0.44 \\
\hline Organic matter \% & 25.9 & - \\
\hline Total phenol (\%) & 0.23 & - \\
\hline Density $\left(\mathrm{gL}^{-1}\right)$ & 1.29 & - \\
\hline \multicolumn{3}{|l|}{ Total nutrients $\%$} \\
\hline $\mathrm{N}$ & 1.44 & 0.002 \\
\hline $\mathrm{P}$ & 0.42 & 0.005 \\
\hline $\mathrm{K}$ & 6.40 & 9.00 \\
\hline
\end{tabular}

The experiments comprise the following treatments:

-Control treatment(Recommended mineral fertilizers dose)

$\bullet 75 \%$ Vinasse $(\mathrm{V} 1)+25 \% \mathrm{~K}_{2} \mathrm{SO}_{4}$

$\bullet 100 \%$ Vinasse (V2)

-75\% Feldspar ( F1) + $25 \% \mathrm{~K}_{2} \mathrm{SO}_{4}$

-100\% Feldspar ( F2)

-25\% Vinasse $+75 \%$ Feldspar

$\bullet 50 \%$ Vinasse $+50 \%$ Feldspar

-75\% Vinasse + 25\% Feldspar

Soil and plant samples:

Soil samples were taken $(0-15 \mathrm{~cm}$ depth) before planting and after harvesting stage air-dried, grounded and passed through a $2.0 \mathrm{~mm}$ sieve for analysis. Cottenie et al. (1982).

Samples from pea and peanut plants were taken at harvesting to determine yield components (straw and grains yield). Plant samples were oven dried at $70 \mathrm{C}$, then ground and digested using $\mathrm{H}_{2} \mathrm{SO}_{4}$ and $\mathrm{H}_{2} \mathrm{O}_{2}$ mixture for $\mathrm{N}, \mathrm{P}$ and $\mathrm{K}$ determinations using Kjeldahl, Spectrophotometer and Flame Photometer apparatus Cottenie et al. (1982). 
For phenolic compounds determine three soil samples were taken after harvesting from each treatment at three soil profile depths $(0-15 \mathrm{~cm}),(15-30 \mathrm{~cm})$ and (30- $45 \mathrm{~cm})$. Phenolic compounds were extracted with methanol using Soxhelt apparatus according to the method described by Cristina et al., (2009) and determined with Ortho-Phenanthroline method according to Gonzalez et al., (2003).

\section{Statistical analysis:}

Standard individual and combined analysis of variance using L.S.D. at 0.05 were performed to estimate the significant differences among treatments according to Snedecor and Cochran (1982).

\section{RESULTS AND DISCUSSION}

- Influence of vinasse and feldspar mineral on soil chemical and physical properties.

\section{A- Chemical properties:}

\section{1- Soil reaction (pH):}

Results in Table (3) revealed that $\mathrm{pH}$ values generally decreased due to application of vinasse and feldspar mineral at both studied seasons. Values decreased gradually by increasing the rates of vinasse or feldspar from $75 \%$ to $100 \%$. Treatment of vinasse $(75$ $\%)$ combined with feldspar $(25 \%)$ was superior in decreasing $\mathrm{pH}$ values at both studied seasons due to the acidic effect of vinasse, organic matter oxidation $\left(\mathrm{H}^{+}\right.$ act as electron acceptor) and high content of free hydrogen ions (Jiang et al., 2012).

\section{2- Electric conductivity (EC):}

Results in Table (3) revealed that EC values in soil at both studied seasons increased due to the application of vinasse. This is possibly due to relatively high concentration of dissolved salts in the vinasse Table (2). Paz et al. (2009) stated that this is due to the high concentration of monovalent cations, particularly sodium.

With respect to interactions Table (3) showed that the highest EC values in soil were recorded for vinasse $(75 \% \mathrm{~V})$ combined with feldspar $(25 \% \mathrm{~F})$ followed by vinasse (V2) at both studied seasons. An opposite trend was encountered with different rates of feldspar (F1and F2) which led to decrease in EC values at both studied seasons as compared to control.

\section{3- Organic matter (OM) \%:}

Data in Table (3) indicated that organic matter content increased with the application of vinasse (V1 and V2) as compared to control. Of course, this may be due to vinasse relatively high content of organic matter Table (2).(Biswas et al., 2009). Furthermore, results showed that the highest values of organic matter content (OM) exist in case of vinasse (V2) and vinasse combined with feldspar $(75 \% \mathrm{~V}+25 \% \mathrm{~F})$ at both studied seasons. These results are in agreement with Arafat and Abd-Elazim (2002) who found that organic matter in soil after harvesting increased with increasing the rate of vinasse applied. On the other hand, the lowest values exist in case of different feldspar rates (F1and F2) at both studied seasons.

\section{4- Availability of macronutrients in soil:}

With regard to macronutrients in soil in both tested seasons Table (3) showed that the values of available macronutrients indicated that application of vinasse (V1andV2) to the soil significantly increased available $\mathrm{N}, \mathrm{P}$ and $\mathrm{K}$ in soil as compared to control treatments. High rate of vinasse (V2) being superior compared to (V1) possibly due to its relatively high content of N, P and K (Biswas et al., 2009).

Statistical interaction analysis revealed that N, P and $\mathrm{K}$ availability in soil increased significantly as consequence of applied vinasse in the presence of feldspar mineral. Moreover, results showed that, vinasse combination with feldspar $(75 \% \mathrm{~V}+25 \% \mathrm{~F})$ recorded the highest values of available $\mathrm{N}, \mathrm{P}$ and $\mathrm{K}$ in soil at both studied seasons. This may be due to its high contents of potassium concentrations Table (2). Furthermore, application of vinasse to soil reduce the nitrogen losses to meet the crop demand for increased plant nitrogen utilization and provides favoring conditions for nitrogen assimilation into the soil, protects nutrients against losses and maintains them as reserve nutrients through slow release during the vegetative period leading to increase yield and quality of crop (Delin and Engstrom, 2010). Moreover, results showed that the lowest values of available $\mathrm{N}$ and $\mathrm{P}$ in soil recorded with control followed by feldspar (F1, F2) for both crops, while the lowest values of available $\mathrm{k}$ recorded with control followed by $(25 \% \mathrm{~V}+75 \% \mathrm{~F})$.

Table 3. Influence of vinasse and feldspar mineral on chemical properties of the tested soil for both seasons

\begin{tabular}{|c|c|c|c|c|c|c|c|c|c|c|c|c|}
\hline \multirow{3}{*}{ Treatments } & \multicolumn{6}{|c|}{ Pea } & \multicolumn{6}{|c|}{ Peanut } \\
\hline & \multirow{2}{*}{ pH } & \multirow{2}{*}{$\begin{array}{c}\mathrm{EC} \\
\mathrm{dSm}^{-1}\end{array}$} & \multirow{2}{*}{$\begin{array}{c}\text { OM } \\
\%\end{array}$} & \multicolumn{3}{|c|}{ Available ( $\left.\mathrm{mg} \mathrm{Kg}^{-1}\right)$} & \multirow{2}{*}{ pH } & \multirow{2}{*}{$\begin{array}{c}\text { EC } \\
\mathrm{dcm}^{-1}\end{array}$} & \multirow{2}{*}{$\begin{array}{c}\mathrm{OM} \\
\%\end{array}$} & \multicolumn{3}{|c|}{ Available ( $\left.\mathrm{mg} \mathrm{Kg}^{-1}\right)$} \\
\hline & & & & $\mathbf{N}$ & $\mathbf{P}$ & $\mathbf{K}$ & & & & $\mathbf{N}$ & $\mathbf{P}$ & $\mathbf{K}$ \\
\hline Control & 7.800 & 0.240 & 0.19 & 180 & 22 & 65.00 & 7.71 & 0.20 & 0.17 & 187 & 25 & 76.00 \\
\hline $75 \%$ Vinasse $(\mathrm{V} 1)+25 \% \mathrm{~K}_{2} \mathrm{SO}_{4}$ & 7.520 & 0.360 & 0.41 & 210 & 38 & 96.80 & 7.45 & 0.30 & 0.50 & 220 & 46 & 100.7 \\
\hline $100 \%$ Vinasse (V2) & 7.430 & 0.430 & 0.50 & 235 & 44 & 106.5 & 7.31 & 0.41 & 0.60 & 240 & 50 & 109.0 \\
\hline $75 \%$ Feldspar $+25 \% \mathrm{~K}_{2} \mathrm{SO}_{4}$ & 7.480 & 0.160 & 0.11 & 198 & 24 & 97.70 & 7.52 & 0.18 & 0.06 & 209 & 28 & 100.0 \\
\hline $100 \%$ Feldspar $(\mathrm{F} 2)$ & 7.520 & 0.180 & 0.10 & 200 & 28 & 103.4 & 7.50 & 0.20 & 0.10 & 217 & 35 & 108.0 \\
\hline$(25 \% \mathrm{~V})+(75 \% \mathrm{~F})$ & 7.600 & 0.260 & 0.24 & 210 & 36 & 85.10 & 7.59 & 0.28 & 0.25 & 216 & 40 & 87.00 \\
\hline$(50 \% \mathrm{~V})+(50 \% \mathrm{~F})$ & 7.510 & 0.320 & 0.30 & 246 & 44 & 111.7 & 7.44 & 0.31 & 0.35 & 255 & 50 & 114.4 \\
\hline$(75 \% V)+(25 \% F)$ & 7.400 & 0.400 & 0.36 & 260 & 58 & 123.0 & 7.36 & 0.38 & 0.42 & 268 & 64 & 125.0 \\
\hline L.S.D at $5 \%$ & 0.091 & 0.018 & 0.04 & 13.1 & 10.2 & 6.30 & 0.054 & 0.030 & 0.06 & 16.0 & 8.2 & 5.50 \\
\hline
\end{tabular}

\section{5- Total phenols content:}

The presence of total phenols within the soil profile after harvesting of both pea and peanut crops due to application of different rates of vinasse alone and/or combined with different rates of feldspar are indicated in (Fig.1).The values of total phenols increased gradually by increasing the concentration of vinasse, as compared to control treatment and decreased gradually with depth. This may be due to the presence of two sources of soil phenols, the first from plant residues and 
the second from applied vinasse. These results agree with those of David and Geoffrey (2010) who reported that, the values of the phenolic compounds for surface soils layer was greater than that for sub soil surface layers. Moreover, the highest values of total phenols were recorded for the soil surface layer in presence of $100 \%$ vinasse alone followed by vinasse combined with feldspar. These values were still less than the maximum values of total phenol allowable in the soil to be contaminated (100 $\mathrm{mg} \mathrm{kg}^{-1}$ soil) according to ILL. S. T. H.A. (2013). These results may be due to the bio degradation of phenolic compound by some soil microorganisms especially in the sandy soil which provide aerobic condition. Mahiuddin et al. (2011) who showed that, degradation of phenols is an important for removing such phenols from the soil thus reducing environmental pollution.

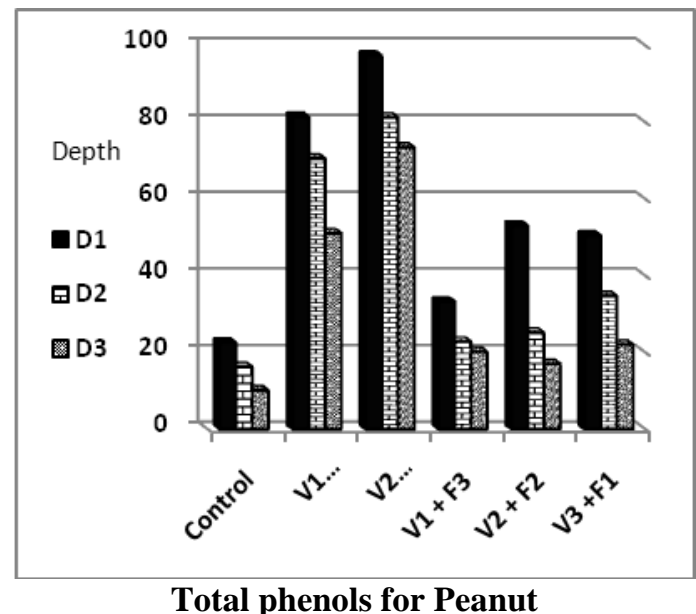

Total phenols for Peanut

Fig. 1 . Effect of applied vinasse alone or combined with different rates of feldspar on total phenols (ppm) in soil after harvesting of both pea and peanut.

\section{B-physical properties:}

\section{- Soil moisture relations:}

Data presented in Fig. (2) indicated that using of different vinasse rates (V1, and V2) to the soil increased field capacity ( FC ), wilting point (WP) and available water (AW) as compared to control at both growing seasons. Also results revealed that the values of FC, WP and AW increased gradually by increasing the rate of vinasse. The high rate of vinasse (V2) was more effective on increasing the values of the studied properties, as compared to the low rate of vinasse $\left(\mathrm{V}_{1}\right)$. Possibly due to its relative high content of organic

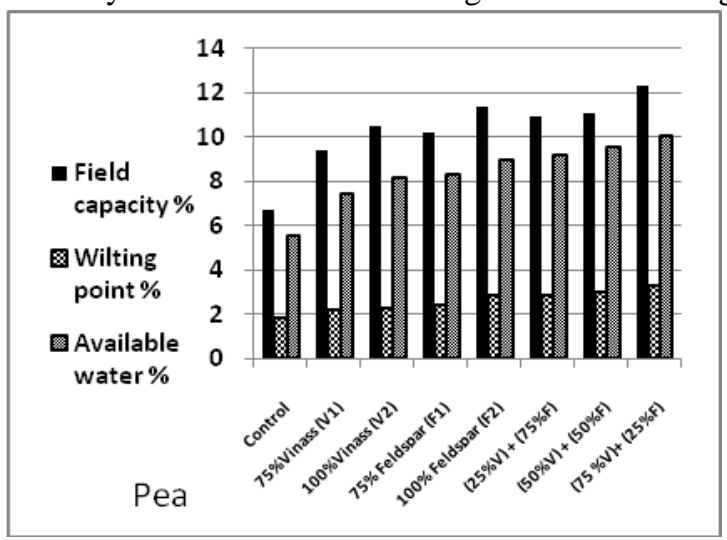

matter that necessary for forming stable aggregates and increased soil structural stability (Tejada et al., 2007).

Regarding the applied feldspar rates (F1and F2), results revealed that it increased field capacity ( FC ), wilting point (WP) and available water (AW) as compared to control at both growing seasons, high rate (F2) was more beneficial. These results are in good agreement with those obtained by (Seddik, 2011) who found that application of feldspar significantly increased both total porosity and available water values of the studied soil as compared with control.

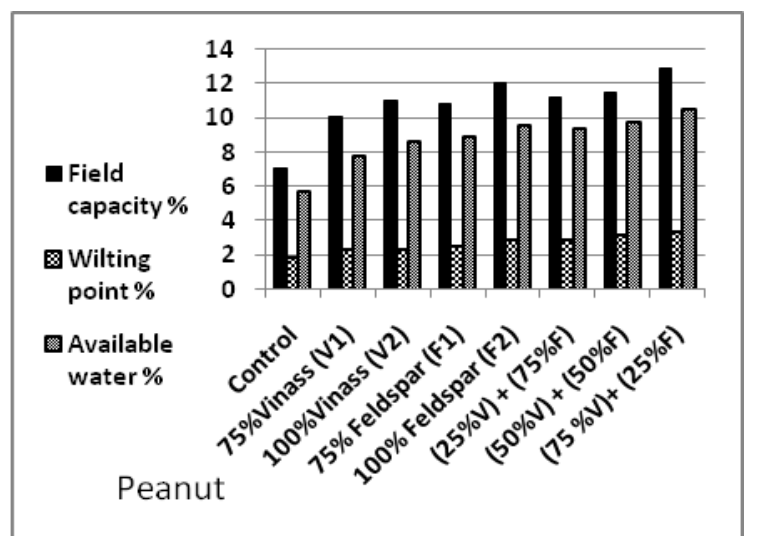

Fig. 2. Influence of vinasse and feldspar mineral on some soil physical properties for both tested crop.

Studying the interaction between both vinasse and feldspar results (Figure 2) indicated that, $75 \%$ vinasse in combination with $25 \%$ feldspar recorded the highest values of field capacity (FC), wilting point (WP) and available water (AW) at both studied seasons. This is due to that the addition of mineral and vinasse together is better than adding them individually. These results are in harmony with those obtained by Seddik and Korany (2004) who found that adding organic residues with natural minerals to soil improve soil moisture retention characteristics and significantly increase peanut, carrot yields. Also, Tejada et al., (2006, 2007) reported that a good soil structure depended on the content and nature of added organic matter which promotes aggregation of clay minerals. 
Recently, Jiang et al., (2012) found that application of vinasse at the rate of $75 \mathrm{t} / \mathrm{ha}$ increased the macro aggregates over farmer practices and had more of larger size aggregates $(>1 \mathrm{~mm})$ with high amount of biodegradable carbon and nitrogen that has more significance to soil fertility. On the other hand, the most inferior treatment for soil moisture content was recorded for no vinasse application (control treatment). This inferiority could be due to absence of organic matter of vinasse.

In general, the present results showed that suggest that $75 \%$ of vinasse combined with $25 \%$ of feldspar (to replace the recommended rate of potassium sulphate) recorded the highest values of soil moisture content (FC, WP and AW) as compared to control or others treatments for both tested crops.

2- Influence of vinasse and feldspar on yield components of pea and peanut.

With respect to yield components of pea and peanut data presented in Table (4) revealed that all applied treatments increased significantly pea and peanut yield components as compared to control treatment.

The applied vinasse rates, results indicated that yield components of pea and peanut decreased significantly along with the application of vinasse rates (V1and V2). This may be due to the relatively high concentration of dissolved salts in the vinasse especially monovalent cations, particularly sodum and phenolic compounds that cause reduced crops (Paz et al., 2009),while , V1 was superior for increasing yield components as compared to V2 . In this respect, Vadivel et al. (2014) found that application different rates of vinasse in agriculture has added a significant amount of nutrients, improved the soil quality of degraded land and increased of crop yields.

As for the effect of feldspar rates (F1, and F2), results revealed that yield components of pea and peanut significantly increased as compared to control treatment; high rate $(\mathrm{F} 4)$ was more beneficial.

Results indicated that pea and peanuts yield components (pods and straw) increased significantly due to applied vinasse and feldspar as compared to control. Moreover, results showed that the highest values of pea and peanuts yield components (pods and straw) were recorded with75\% vinasse combined with $25 \%$ feldspar (V3+ F1) as compared to other treatments. These may be due to the beneficial effect of vinasse on stimulating micro flora populations, and increase of microbial biomass thus enhancing the soil fertility status and improve crop production (Saliha, 2005 and ShangDong et al., 2013). Also, vinasse produces organic acids which can directly enhance release of $\mathrm{K}$ from feldspar by either protons or ligand-mediated mechanisms. They can also indirectly enhance dissolution by the formation of complexes in solution and as a consequence increase the chemical affinity for the overall dissolution reaction (Ullman and Welch, 2002) and (Seddik, 2011).

Furthermore, results showed that the lowest value of pea and peanuts yield components existed in case of vinasse (V2) at both studied seasons. Treatments of concentrated vinasse and feldspar mineral may be arranged as follows: $75 \%$ vinasse combined with $25 \%$ feldspar (V3+ F1) $>50 \%$ vinasse combined with $50 \%$ feldspar (V2+ F2)> $25 \%$ Vinass combined with $75 \%$ feldspar.

Table 4. Yield components of pea and peanut as affected by application vinasse and feldspar mineral

\begin{tabular}{lcccc}
\hline \multirow{2}{*}{ Treatments } & \multicolumn{2}{c}{$\begin{array}{c}\text { Pea yield ton } \\
\text { fed. }\end{array}$} \\
& Pods & Straw & \multicolumn{2}{c}{$\begin{array}{c}\text { Peanut yield } \\
\text { ton fed. }\end{array}$} \\
& Pods & Straw \\
\hline Control & 1.82 & 1.70 & 1.60 & 1.62 \\
75\%Vinasse $(\mathrm{V} 1)+25 \% \mathrm{~K}_{2} \mathrm{SO}_{4}$ & 2.40 & 2.00 & 2.40 & 1.90 \\
100\%Vinasse (V2) & 2.20 & 1.80 & 2.00 & 1.80 \\
75\% Feldspar + 25 \% $\mathrm{K}_{2} \mathrm{SO}_{4}$ & 2.50 & 2.00 & 2.50 & 1.96 \\
$100 \%$ Feldspar (F2) & 2.80 & 2.10 & 2.80 & 1.80 \\
$(25 \% \mathrm{~V})+(75 \% \mathrm{~F})$ & 3.10 & 2.70 & 2.90 & 1.90 \\
$(50 \% \mathrm{~V})+(50 \% \mathrm{~F})$ & 3.40 & 2.80 & 3.20 & 2.12 \\
$(75 \% \mathrm{~V})+(25 \% \mathrm{~F})$ & 3.80 & 3.00 & 3.64 & 2.30 \\
L.S.D at 5\% & 0.15 & 0.04 & 0.096 & 0.10 \\
\hline
\end{tabular}

\section{3- Influence of vinasse and feldspar on total contents} of macronutrients for pea and peanut crops:

The total contents of macronutrients (N, P and K) of pea and peanut (seeds and straw) are shown in Table (5).

Results indicated that values of $\mathrm{N}, \mathrm{P}$ and $\mathrm{K}$ total contents of seeds and straw for both pea and peanut crops, generally increased due to application of vinasse, and feldspar were applied alone or in combination as compared to control treatment. Moreover, vinasse (V1) and feldspar (F2) gave significantly favorable macronutrients total content in seeds and straw for both pea and peanut crops. While the lowest values of N, P and K total content were recorded with (V2) treatment. This may be due to the fact that vinasse contains much more sodium than potassium given an antagonistic relationship between $\mathrm{Na}$ and $\mathrm{K}$; higher absorption could have reduced plant $\mathrm{K}$ absorption. (Mansoori et al., 2014).

Table. 5. Responses of some macronutrients total contents of pea and peanut ( seeds and straw) to the application of vinasse and feldspar mineral.

\begin{tabular}{|c|c|c|c|c|c|c|c|c|c|c|c|c|}
\hline \multirow{4}{*}{ Treatments } & \multicolumn{12}{|c|}{ Macronutrient total contents $\left(\mathrm{kg} \mathrm{fed}^{-1}\right)$} \\
\hline & \multicolumn{6}{|c|}{ Pea } & \multicolumn{6}{|c|}{ Peanut } \\
\hline & \multicolumn{3}{|c|}{ Seed } & \multicolumn{3}{|c|}{ Straw } & \multicolumn{3}{|c|}{ Seed } & \multicolumn{3}{|c|}{ Straw } \\
\hline & $\mathbf{N}$ & $\mathbf{P}$ & $\mathbf{K}$ & $\mathbf{N}$ & $\mathbf{P}$ & $\mathbf{K}$ & $\mathbf{N}$ & $\mathbf{P}$ & $\mathbf{K}$ & $\mathbf{N}$ & $\mathbf{P}$ & $\mathbf{K}$ \\
\hline Control & 21.20 & 5.10 & 15.52 & 20.52 & 3.44 & 16.11 & 32.10 & 9.21 & 13.20 & 15.40 & 4.91 & 20.00 \\
\hline $75 \%$ Vinasse $(\mathrm{V} 1)+25 \% \mathrm{~K}_{2} \mathrm{SO}_{4}$ & 23.40 & 10.13 & 18.00 & 24.00 & 9.00 & 19.00 & 40.00 & 14.52 & 20.40 & 24.00 & 10.54 & 30.11 \\
\hline $100 \%$ Vinasse (V2) & 22.00 & 8.11 & 17.21 & 23.15 & 8.80 & 18.44 & 35.30 & 13.00 & 17.00 & 22.11 & 9.01 & 29.20 \\
\hline $75 \%$ Feldspar $+25 \% \mathrm{~K}_{2} \mathrm{SO}_{4}$ & 23.30 & 8.40 & 19.40 & 24.00 & 8.55 & 21.11 & 36.31 & 13.64 & 18.55 & 23.41 & 9.60 & 35.00 \\
\hline $100 \%$ Feldspar $(\mathrm{F} 2)$ & 27.51 & 9.67 & 27.20 & 29.11 & 9.44 & 28.06 & 37.20 & 14.56 & 21.00 & 25.50 & 10.00 & 36.20 \\
\hline$(25 \% \mathrm{~V})+(75 \% \mathrm{~F})$ & 30.20 & 18.22 & 29.60 & 29.09 & 14.00 & 31.00 & 40.20 & 18.50 & 21.00 & 27.41 & 10.00 & 43.0 \\
\hline$(50 \% \mathrm{~V})+(50 \% \mathrm{~F})$ & 33.00 & 16.70 & 32.00 & 32.14 & 14.20 & 33.11 & 44.00 & 22.35 & 25.12 & 31.60 & 12.56 & 48.3 \\
\hline$(75 \% V)+(25 \% F)$ & 38.12 & 26.41 & 35.10 & 37.10 & 17.33 & 36.23 & 51.61 & 24.60 & 30.20 & 36.70 & 16.80 & 55.32 \\
\hline L.S.D at $5 \%$ & 3.60 & 2.80 & 2.00 & 2.06 & 2.31 & 1.93 & 2.03 & 1.90 & 2.42 & 2.11 & 1.44 & 1.23 \\
\hline
\end{tabular}


The obtained results as interactions among the influences of vinasse in the presence of feldspar such interactions are shown in Table (5). Results indicated that, $75 \%$ vinasse combination with $25 \%$ feldspar recorded the highest values of $(\mathrm{N}, \mathrm{P}$ and $\mathrm{K})$ total content of seeds and straw for both pea and peanut crops. Also, application of vinasse increased significantly $\mathrm{N}, \mathrm{P}$ and $\mathrm{K}$ uptake as well as yield of sugarcane, wheat, pigeon pea and maize yield (Komdorfer and Anderson, 1993). While the lowest values of $\mathrm{N}, \mathrm{P}$ and $\mathrm{K}$ total contents were recorded with $\mathrm{V} 2$ treatment.

Generally, the behavior of macronutrients uptake followed the same trend of those recorded by yield components. The treatments can be generally arranged as follows: $(75 \% \mathrm{~V}+25 \% \mathrm{~F})>(50 \% \mathrm{~V}+50 \% \mathrm{~F})>$ $(25 \% \mathrm{~V}+75 \% \mathrm{~F})$

\section{CONCLUSIONS}

Form the obtained results, it could be concluded that vinasse and feldspar mineral increased availability of macronutrients in the experimental soil and improved soil moisture content (FC, WP and AW). Also, the use of vinasse as a source of $\mathrm{K}$ - fertilizers does not cause any bioaccumulation of phenol compounds in the sandy soil profile because of easily decomposition in sandy soils.

As conclusion, the importance of the use of ( vinasse and feldspar) alone or in combination be considered to be an alternative sources for K-fertilizers and beneficial cheap sources of K-fertilization for agriculture in sandy soils of Egypt.

\section{REFERENCES}

Abd El-Motty, Elham Z., M. F. M. Shahin, M. M. Abd ElMigeed and A. F. Sahab (2009). Comparative studies of using compost combined with plant guard and flespar on the morphological, physiological and rhizospheric microflora of olive seedlings. American-Eurasian J. Agric. and Environ. Sci., 6: 372-380.

Arafat, S. and Y. Abd-Elazim. (2002). Agronomic evaluation of fertilizing efficiency. Symposium no. 14. 17th WCSS, $14-21$ August. Thailand. $1991-1$ $1991-6$

Armengol, J., E. Lorenzo and F. Noemi. (2003). Use of vinasses dilutions in water as an alternative for improving chemical properties of sugarcane planted vertisols. Cultivostropicales. 24(3):73-76.

Badr, M. A. (2006). Efficiency of K-feldspar combined with organic materials and silicate dissolving bacteria on tomato yield. J. Appl. Sci. Res. 2: 11911198.

BioBizz Worldwide (2011). Petition: Vinasse for Organic Crop Production. Retriev ed. January 9, 2013 from, http://www.ams.usda.gov/AMSv1.0/getfile?dDocN ame=STELPRDC5097665.

Biswas, A. K., M. Mohanty, K. M. Hati and A. K. Misra. (2009). Distillery effluents effect on soil organic carbon and aggregate stability of a Vertisol in India, Soil. Till. Res. 104:241-246. http://dx.doi.org/ 10.1016/j.still.2009.02.012.
Cottenie, A., M. Verloo, L. Kiekns, G. Velghe and R. Camerlynek. (1982). "Chemical Analysis of Plant and Soils". Lab. Analy. andAgroch St. State Univ., Ghent, Belgium.

Cristina, M. S., Z. S. Ferrera, M. E.T. Padron and J. J. S. Rodriguez. (2009). Methodologies for the extraction of phenolic compounds from environmental samples: New Approaches Molecules .14, 298-332.

David, L. R. and D. A. Geoffrey. (2010). Phenolic compounds in $\mathrm{NaOH}$ extracts of UK soils and their contribution to antioxidant capacity .The World Congress of Soil Science, Soil Solutions for a Changing World1- 6 August 2010, Brisbane, Australia.

Delin, S. and L. Engstrom. (2010). Timing of organic fertiliser application to synchronise nitrogen supply with crop demand." Acta Agriculturae Scandinavica, Section B - Soil. Plant Sci. 60(1):7888.

Figaro, S., L. S. Lais and J. Lambert. (2006). Adsorption studies of recalcitrans compounds of molasses spent wash on activated carbons, Water Resources, 40 (3459-3466).

Filho, O. J. C., V. Bittencourt and M. C. Alves. (1996). Vinasse application in a brazilian sandy soil and nitrogen water table pollution, Proceed. Int. Soc. Sugarcane Technol. Cartagena Colombia 22(2):6366.

Gonzalez, M., B. Guzman, R. Rudyk, E. Romano and A. A. Molina. (2003). Spectrophotometric determination of phenolic compounds in propolis. Lat. Am. J. Pharm. 22(3) 243-348.

ILL, S. T. H. A. (Illinois Stat Toll Highway Authority). (2013). Guidelines for management of clean construction or demolitondebris (CCDD), uncontaminated soil used as offsite fill and contaminated soil .DESIGN BULLETIN NO.1301 .

Jiang, Z. P., Y. R. Li, G. P. Wei, Q. Liao, T. M. Su, Y. C., H.Y. Meng Zhang and C.Y. Lu. (2012). Effect of long-term vinasse application on physico-chemical properties of sugarcane field Soils. Sugar Technol. 14(4):412-417. http://dx.doi.org/10.1007/s12355012-0174-9.

Komdorfer, G. H. and D. L. Anderson. (1993).Use and impact of sugar - alcohol residues vinasse and filter on sugarcane production in brazil. In Proc. Of inter American Seminor 122. Miami,USA, 15-17, 164170.

Luz, P. H. C. (2005). "Novas Tecnologiasno Uso de Vinhacae Alguns Aspectos legais," 11 simpsio de Tecnologia de produce de Accar, Pirassunuga, S. paulo, 53 .

Mahimairaja, S. and N. S. Bolan. (2004). Problems and prospects of agricultural use of distililery spent wash in india, In: Proc. of Super soil 3rd Australian and New-Zealand soils conference, December, University of Sydney, Australia. pp5-9 
Mahiuddin, M. D., A. N. M. Fakhruddin and A. M. Abdullah. (2011). Degradation of Phenol via Meta Cleavage Pathway by Pseudomonas fluorescens PU. International Scholarly Research Notices. vol.6.

Mansoori, M., M. A. Fazel, A. Jorfi and M. Machal.(2014)Effect of salinity stress on nutrient uptake of sugarcane genotypes. Nova J. of Eng. and Applied Sci. $2: 1-8$

Osman, Mona A. (2010). The Possible Use of Diluted Vinasse as A Partial Replacement with Mineral Fertilizers Source on Wheat Yield and Nutritional Status on Sandy Soil. Nature and Science. 8(11): 245-251.

Osman, Mona A., Wafaa M. A. Seddik and Mona H. M. Kenawy. (2016). Agronomic evaluation of diluted vinasse as a source of potassium fertilizers for peanut and carrot crops. J. Soil Sci. and Agric. Eng., Mansoura Univ., Vol. 7(2):107116

Parnaudeau, V., N. Condom, R. Oliver, P. Cazevieille and S. Recous. (2007). Vinasse organic matter quality and mineralization potential, as influenced by raw material, fermentation and concentration processes. (C.F Science directBioresource Technology. Copyright@2007 Elsevier Ltd All rights reserved).

Paz, C. B., J. A. M. Rub, R. G. Ginenez and R. J. Ballesta. (2009). Impacts caused by the addition of wine vinasse on some chemical and mineralogical properties of a Luvisol and Vertisol in La Mancha. Journal of Soils and Sediments. 121-128.

Rodriguez, J. G. (2000). Effect of vinasse on sugarcane (Saccharumofficinarum) productivity. Rev. Fac. Argon., 17: 318 - 326.

Saliha, B. (2005). Distillery spent wash for sustainable soil health. Kisan World 32(18):50-51.

Seddik, Wafaa M. A. (2006). Effect of organic manures and feldspar application on some sandy soil physical and chemical properties and their refection on peanut productivity. J. Agric. Sci., Mansoura Univ., Egypt. 33; 6675 - 6687.
Seddik, Wafaa M. A. (2011). Evaluation of vinasse, organic manure and natural minerals as alternative natural fertilizers. J.Bio.Chem.Environ.Sci.6:269292.

Seddik, Wafaa M. A and Laila, M. A. Korany. (2004). Effect of some natural soil amendments on some soil physical properties, peanut and carrot yields in sandy soil. J. Agric. Res.,Egypt. 82: 95 - 105.

Shang-Dong,Y., L. Jun-Xian, W. Jun, T. Hong-Wei and L. Yang-Rui.(2013). Effect of vinasse and press mud application on the biological properties of soils and productivity of sugarcane. Sugar Technol .15:152158.

Silva, J., J. Cazetta and A. Togoro. (2015). Soil change induced by the application of biodigested vinasse concentrate and its effects on growth of sugarcane.

Snedecor, G. W. and W. G. Cohran. (1982). "Statistical Methods". 7 th Edition. Lowa State Univ. Press. Amer. 1. A, USA.

Tate and Lyle.(2005). Material Safety Data Sheet Condensed Molasses Solubles (CMS) and Technical Datasheet: Vinasse MPCV 01

Tejada, M., C. Garcia, L. Gonzalez and M. T. Hernandez. (2006). Organic amendment based on fresh and composted beet vinasse: Influence on soil properties and wheat yield. Soil Sci. Soc. Amer. J., 70:900908.

Tejada, M., J. L. Moreno, M. T. Hernandez and C. Garcia. (2007). Application of two beet vinasse forms in soil restoration: Effects on soil properties in an arid environment in southern Spain. Agriculture, Eco systems and environment 119; $289-298$.

Ullman, W. J. and S. A. Welch. (2002). Organic ligands and feldspar dissolution. The geochemist. Soc., 7: 3 -35 .

Vadivel, R., S. M. Paramjit, K. P. Suresh, S. Yogeswar, R. D. V. K. Nageshwar and N. Avinash. (2014). Significance of vinasses waste management in agriculture and environmental quality- Review. African J. Agric. Res. 9, 2862-2873.

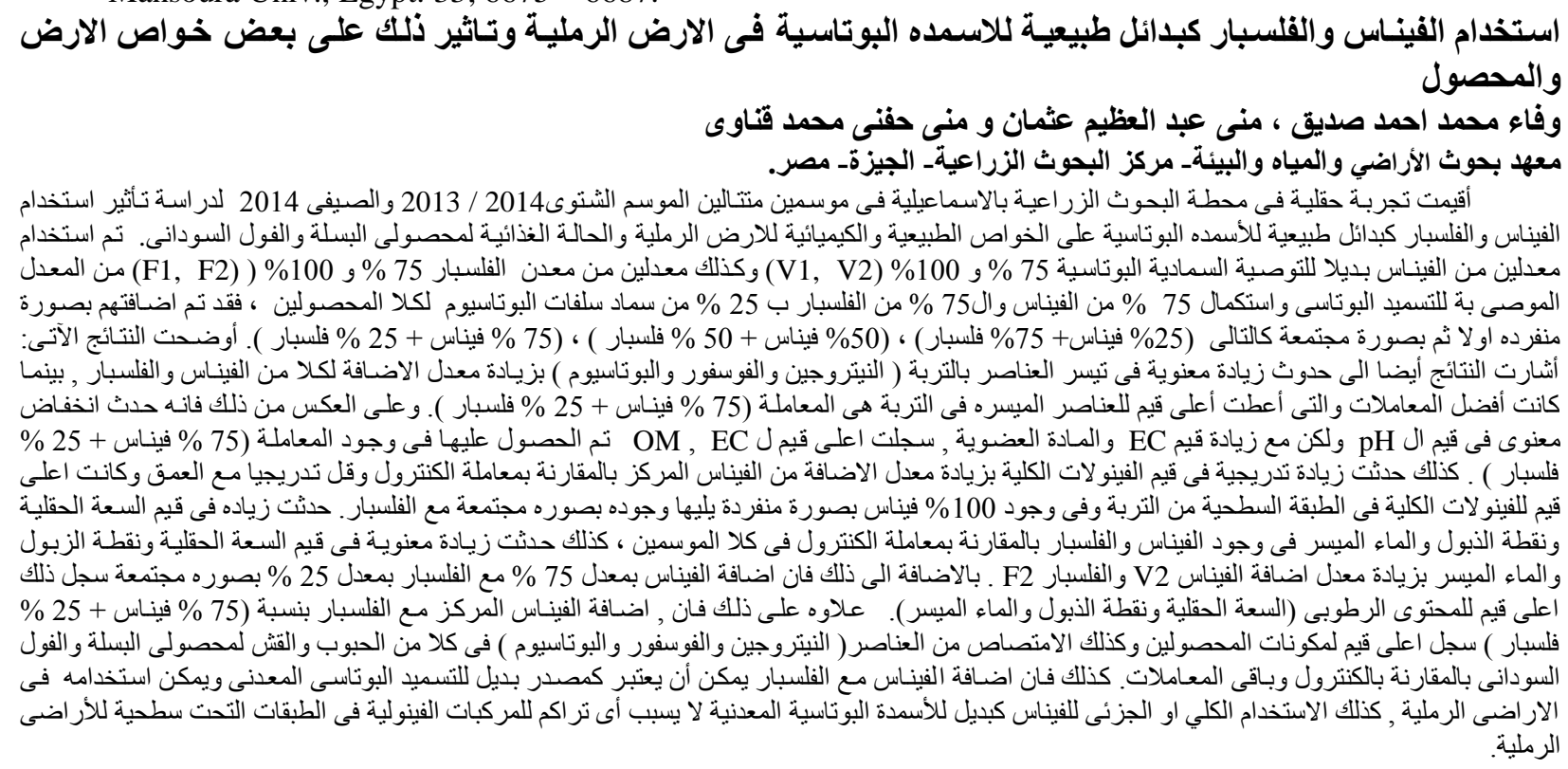

